\title{
Proclivity for Open Innovation in the Case of Agricultural and Food Companies in Serbia
}

\author{
ZAKIĆ Nebojša ${ }^{20}$, BUGARČIĆ Marina ${ }^{21}$, \\ MILOVANOVIĆ Marina ${ }^{22}$
}

\begin{abstract}
The approach to open innovation presents one of the major trends in terms of constant change and accelerating technological innovation. The given construct proclivity for open innovation involves measuring technology exploration and technology exploitation involving different inside-out and outside-in open innovation activities. In this paper, we are researching the tendency for open innovation on a sample of 102 companies in the agriculture and food sectors in Serbia. The research has shown that companies in the agro-food sector are inclined to open innovation, not just those in high-tech industries that are often the subject of innovation literature. The food sector shows greater proclivity for open innovation in comparison with agriculture in all elements apart from the question of willingness to sell intellectual property.

The study was limited to Serbia and cross-countries research would allow establishing the specificities and differences of the proclivity for open innovation in the agro-food sector by regions.
\end{abstract}

Keywords: Proclivity for open innovation, Technology exploitation, Technology exploration, Agro-food sector, Serbia

JEL: O31, M13, L24, L66, Q10

UDK: 005.591.6

005.521:334.72:631.1(497.11)

COBISS.SR-ID 253499148

\section{Introduction}

Open innovation as a new paradigm for managing innovation, introduced by Chesbrough (2003), shortly thereafter developed into a special research area and has become one of the most current subjects in innovation management (Huizingh 2011). In accordance with Chesbrough et al., (2006) open innovation is defined as "the use of purposive inflows and outflows of knowledge to accelerate internal innovation, and expand the markets for external use of innovation, respectively." The basic idea behind open innovation is to open up the innovation process to other organizations (Chesbrough et al., 2006) in order to allow the unimpeded flow of ideas within and outside the organization and, in this way, bring out the advantage of exploration of external and exploitation of internal resources (Chesbrough 2003).

20 Faculty of entrepreneurial business, "Union - Nikola Tesla" University, Belgrade, Serbia, nebojsazakic@gmail.com

21 Faculty of entrepreneurial business, "Union - Nikola Tesla" University, Belgrade, Serbia, bugarcicm.vbps@gmail.com

22 Faculty of entrepreneurial business, "Union - Nikola Tesla" University, Belgrade, Serbia, milovanovicmm@gmail.com 
The literature points out that the prospect of open innovation first found its place in multinational companies and high-technology industries and in situations where the focus is on emerging technologies (van de Vrande et al., 2009; Herzog 2011). Although Open Innovation approach started to evolve from the research of high-tech multinationals, Chesbrough and Crowther (2006) found that firms through a wide range of low technology and mature industries can also apply open innovation. In addition, the size of the company is not an obstacle for the implementation of open innovation. According to van de Vrande et al., (2009) open innovations are relevant and present in business practice in much broader group of small and medium-sized enterprises. Small companies often lack the resources to develop and commercialize new products that encourage them to cooperate with other organizations (van de Vrande et al., 2009). Accordingly, a research base has increased. Hossain (2015) finds out that 61 articles published between 2003 and 2014 can be found in the relevant scientific databases on the subject of small businesses and open innovation.

The evidence proving the approach of open innovation spread to agro-industrial sector has been growing (Sarkar, Costa 2008; Matras-Bolibok, Kiss 2014). Agriculture is becoming more complex by its nature existing in an environment characterized by rapid global, technological, market and social changes. Continuous and consistent improvement of technological and organizational skills, putting a strong emphasis on innovation, which are crucial for the organization's sustainability, development and competitive advantage (Pishbin et al., 2015).

According to Matras-Bolibok and Kiss (2014) open systems approach to agricultural innovation becomes an adequate vehicle for invigorated farmers to explore new options in order to make their businesses more viable and sustainable.

In the food industry, which is considered to be traditional and low tech, there has been a big change from the beginning of the $21^{\text {st }}$ century. Innovations in this area are moving towards open innovation as Acosta et al., (2011) explains by the fact that innovations are initially introduced in small companies that lack the know-how necessary for commercialization; food industry does not rely only on its own $\mathrm{R} \& \mathrm{D}$, but learns and interacts with different participants; and knowledge useful for companies in the food industry comes from various sectors such as agriculture, pharmaceuticals, chemical industry, process industry and emergent scientific and technological fields such as biotechnology.

Agro-industrial sector plays an important role in the economy of Serbia. According to the Strategy of Agriculture and Rural Development of Serbia for the period 2014-2024 (2014) in 2024, agriculture should be the sector whose development is based on knowledge, modern technologies and standards, domestic and demanding foreign markets offering innovative products and manufacturers provide a viable and stable income. Similarly, Strategy and policy development of the industry of the Republic of Serbia 2011-2020 (2011) predicts the growth of industrial production, investment, innovation and exports, as well as speeding up the reform process. If we take into account environmental factors that have a strong influence on agriculture and food industry of Serbia, such as globalization, the rise of competition, the process of Serbia's European integration, technological changes, changes in the needs and preferences of customers, etc., as well as the projections of strategic documents, innovation is one of the keys of profitability and competitive advantage in the agro-industrial sector in Serbia.

Innovations are the most important drivers in contemporary economies (Vukovic et al., 2016) and much of the efforts policy makers and many other stakeholders aim to support innovation. Although, today in Serbia, the importance of innovation is understood as one of the main levers of success in enterprises of agro-industrial sector in Serbia, innovation processes in small and medium-sized enterprises are still ineffective and unsystematic. According to the approach to open innovation, an organization cannot innovate in isolation; it must be connected with different types of partners to gain ideas and resources from the environment to keep pace with the competition (Dahlander, Gann 2010). The question is whether the concept of open innovation finds its place in agricultural food sphere in Serbia, whether small, medium and large companies in the agro-industrial sector are prone to open innovation or traditionally the sector is still closed and reluctant for such innovations. According to Schoeffel (2014), 
preference for open innovation is defined as the inclination or predisposition of organizations to use different elements of open innovation in the innovation process. Preference for open innovation is conceptualized by Huang and Chiang (2010) as the evaluation of the inclination of companies to integrate external ideas to supplement its business model in order to pursue innovation success and gauge the tendency for companies to profit from outsiders' underutilized use of its intellectual property. However, the construct the authors have developed to measure firm-level open proclivity is incomplete, including collaboration and selling/buying intellectual property, but ignoring some important open innovation activities that have been highlighted in previous literature as venturing, engaging the customer and external participation. Rangus (2014) develops a proclivity for open innovation construct a more multi-dimensional in nature and is based on the basic work of previous authors (van de Vrande et al., 2009; Chesbrough/Crowter, 2006, etc.).

In accordance with Venturiny et al., (2013) the approach to open innovation is based on two main dimensions: technology exploitation and exploration technology involving different kinds of practice outside-in (inbound) and inside-out (outbound) open innovation activities. In the first set of innovational practices (technology exploitation), according to van de Vrande et al., (2009) venturing refers to starting up new organizations relying on internal know-how and other support services from the organization concerned; outward IP licensing is selling or offering licenses to other organizations to better benefit from the intellectual property of concerned organizations and employee involvement is leveraging the knowledge and initiative of employees by enabling them to implement ideas and participate in the implementation of innovations. In the second set of innovative practices, according to van de Vrande et al., (2009) customer involvement is a direct involvement of customers in the innovation processes of the organization concerned; external networking is relying on cooperation with network partners to support the innovation process; external participation has equity investments in other companies to obtain access to their knowledge; outsourcing R \& D is buying R \& D services from other organizations (notably knowledge institutions) and inward licensing IP is the purchase or use of intellectual property from other organizations. The review of open innovation practices according to de Vrande et al., (2009) is given in Table 1 (first column).

Practically, the construct readiness for open innovation should include each of the above activities. Rangus (2014) introduces a simplification for the part that relates to exploration technology, emphasizing that external participation and inward IP licensing in essence reflect one dimension of open innovation. This also applies to external networking and outsourcing $\mathrm{R}$ \& D. In accordance with the Rangus (2014), a review of open innovation practices is given in Table 1 (second column).

Table 1. Overview of open innovation practices

\begin{tabular}{|l|l|}
\hline \multicolumn{2}{|c|}{ Technology exploitation } \\
\hline \multicolumn{2}{|c|}{ Van de Vrande et al. (2009) and Rangus (2014) } \\
\hline \multicolumn{2}{|c|}{ Outwaring } \\
\hline \multicolumn{2}{|c|}{ Employee involvement } \\
\hline \multicolumn{2}{|c|}{ Technology exploration } \\
\hline Van de Vrande et al. (2009) & \multicolumn{1}{c|}{ Rangus (2014) } \\
\hline Customer involment & Customer involvement \\
\hline External networking & Outsourcing R\&D \& External networking \\
\hline External participation & External participation \& Inward IP licensing \\
\hline Outsourcing R\&D & \\
\hline Inward IP licencing & \\
\hline \multicolumn{2}{|c|}{ Source: Adapted from van de Vrande et al. (2009) and Rangus (2014) }
\end{tabular}

In this way, the construct proclivity for open innovation consists of two dimensions and six elements: venturing, outward IP licensing, employee involvement, customer involvement, outsourcing R \& D \& external networking and external participation inward \& IP licensing. 
Based on this, we developed a research instrument with twelve items, two for each of the elements, using the relevant literature (Rangus 2014; Hung/Chiang 2010; van de Vrande 2009; Chesbrough/Crowter 2006, etc.). The study included professors, external experts, company executives, experts in companies and farmers who estimated that 6 out of 12 items may have been excluded due to redundancy, similarities and reflecting the same aspect of proclivity for open innovation.

\section{Material and methods}

In the study included a hundred and four (104) participants (companies) divided into two groups of fifty-two (52). The first group was comprised of participants from the agricultural sector (perennial crops cultivation, perennial crops growing, planting material growing, farming, mixed farming), while the second group was comprised of participants from the sectors of food products (meat and meat products processing and preserving, processing and preserving of fruits and vegetables, production of vegetable and animal oils and fats, dairy production, grain mill products, starches and starch products, bakery products and pasta, production of other food products). Ten respondents were from large enterprises, others were from small and medium-sized enterprises.

The final list of questions was the following:

1. We use external sources of knowledge/technology when developing new activities. (Venturing)

2. We are willing to sell a part of our intellectual property rights to other organizations. (Outward IP licensing)

3. We provide information to employees about the importance of innovation for our business? (Employee Involvement)

4. Our organization is willing to invest in a new company to achieve access to knowledge/technology. (External participation \& IP licensing inward)

5. Our customers are involved in the process of testing a new product/service? (Customer involvement)

6. We work with universities, institutes, laboratories and similar organizations providing knowledge in order to acquire new knowledge/technology? (Outsourcing R \& D \& external networking)

Replies to the questionnaire were designed based on the Likert scale (reference) of seven divisions so that each respondent could express their level of agreement or disagreement.

The questions in our research were planned in the form of the following six variables:

var 1 - readiness to use external sources of knowledge/technology to develop new activities; var 2 - measures of willingness to sell part of its intellectual property to other organizations; var 3 - willingness to inform employees about the importance of information for business; var 4 - willingness to invest in a new company to achieve access to knowledge/technology;

var 5 - degree of willingness of respondents to involve users in the process of testing new products/services;

var 6 - measures of cooperation with universities, institutes, laboratories and similar organizations of knowledge in order to acquire new knowledge/technology.

\section{Results and discussion}

Using a statistical method - Mann-Whitney test for independent samples and the software package SPSS for Windows (version 16.0), we compared the differences between the two independent groups of respondents from mentioned sectors (Table 1). The result was considered statistically significant if the probability $\mathrm{p}<0.05$.

A detailed overview of the frequency of respondents for each of the questions (variables) can be seen from Tables 2 and 3 . 
Results of Mann-Whitney test show that there is a statistically significant difference between the groups of respondents from agricultural sector and in the sector of food production with regard to:

- the degree of readiness to use external sources of knowledge/technology (var 1$),(\mathrm{Z}=$ $2,120, \mathrm{p}=0.034) ; 41.2 \%$ of respondents in the agricultural sector and $56.8 \%$ in the food sector expressed readiness to use external sources of knowledge/technology to develop new activities;

- measures of willingness to sell intellectual property rights to other organizations (var $2),(Z=-3,214, p=0.001) ; 28.4 \%$ of respondents from the agricultural sector stated that they were willing to sell part of their intellectual property, while the percentage is much lower in the food sector $(15.7 \%)$;

- readiness to inform employees about the importance of information for business (var $3),(Z=-3,582, p=0.000)$; the study showed that $17.6 \%$ of respondents in the agricultural sector considers it necessary to inform employees about the importance of information for business, while the percentage in the food sector was significantly higher (34.3\%);

- the degree of willingness of respondents to involve users in the process of testing a new product/service (VAR 5), $(\mathrm{Z}=-3,268, \mathrm{p}=0.000) ; 39.2 \%$ of the employed in the agricultural sector, and even $64.6 \%$ of employees in the food sector is ready to rely on setting up a new business relying on internal knowledge/technology.

The results of Mann-Whitney test for two independent samples also showed no statistically significant difference in terms of:

- willingness to invest in a new company to achieve access to knowledge/technology (var 4), $(Z=-1,258, p=0.208)$ and

- extent of cooperation with universities, institutes, laboratories and similar organizations providing knowledge in order to acquire new knowledge/technology (var 6), $(Z=-1,309$, $\mathrm{p}=0.191)$.

Table 2. The results of Mann-Whitney test for two independent groups of respondents from agricultural sector and the sector of food production by variables

\begin{tabular}{|l|r|r|r|r|r|r|}
\hline & \multicolumn{1}{|c|}{ var 1 } & \multicolumn{1}{c|}{ var 2 } & \multicolumn{1}{c|}{ var 3 } & \multicolumn{1}{c|}{ var 4 } & \multicolumn{1}{c|}{ var 5 } & \multicolumn{1}{c|}{ var 6 } \\
\hline $\begin{array}{l}\text { Mann- } \\
\text { Whitney U }\end{array}$ & 988.000 & 827.000 & 773.500 & 1115.000 & 820.500 & 1108.000 \\
\hline Wilcoxon W & 2314.000 & 2153.000 & 2099.500 & 2441.000 & 2146.500 & 2434.000 \\
\hline Z & -2.120 & -3.214 & -3.582 & -1.258 & -3.268 & -1.309 \\
\hline $\begin{array}{l}\text { Asymp. Sig. } \\
\text { (2-tailed) }\end{array}$ & 0.034 & 0.001 & 0.000 & 0.208 & 0.001 & 0.191 \\
\hline
\end{tabular}

Source: Own research

Table 3. Frequency response to the above-mentioned questions (by marked variables) of respondents from agricultural sector and the sector of food production

\begin{tabular}{|c|c|c|c|c|c|c|c|c|}
\hline \multicolumn{2}{|c|}{$\begin{array}{l}\text { Offered responses } \\
\text { Frequency N } \\
\text { (Percent \%) }\end{array}$} & $\begin{array}{c}1 \\
N \\
(\%) \\
\end{array}$ & $\begin{array}{c}2 \\
\mathrm{~N} \\
(\%)\end{array}$ & $\begin{array}{c}3 \\
\mathrm{~N} \\
(\%)\end{array}$ & $\begin{array}{c}4 \\
\mathrm{~N} \\
(\%)\end{array}$ & $\begin{array}{c}5 \\
\mathrm{~N} \\
(\%) \\
\end{array}$ & $\begin{array}{c}6 \\
\mathrm{~N} \\
(\%) \\
\end{array}$ & $\begin{array}{c}7 \\
\mathrm{~N} \\
(\%)\end{array}$ \\
\hline \multirow{2}{*}{$\begin{array}{l}\text { var } \\
1\end{array}$} & $\begin{array}{l}\text { Agricultural } \\
\text { sector }\end{array}$ & $\begin{array}{c}5 \\
(9.81)\end{array}$ & $\begin{array}{c}8 \\
(15.69)\end{array}$ & $\begin{array}{c}7 \\
(13.73)\end{array}$ & $\begin{array}{c}10 \\
(19.61)\end{array}$ & $\begin{array}{c}6 \\
(11.77)\end{array}$ & $\begin{array}{c}12 \\
(23.50)\end{array}$ & $\begin{array}{c}3 \\
(5.88)\end{array}$ \\
\hline & $\begin{array}{l}\text { Food produ- } \\
\text { ction sector }\end{array}$ & $\begin{array}{c}0 \\
(0)\end{array}$ & $\begin{array}{c}4 \\
(7.84)\end{array}$ & $\begin{array}{c}10 \\
(19.61)\end{array}$ & $\begin{array}{c}8 \\
(15.69)\end{array}$ & $\begin{array}{c}9 \\
(17.65)\end{array}$ & $\begin{array}{c}10 \\
(19.61)\end{array}$ & $\begin{array}{c}10 \\
(19.61)\end{array}$ \\
\hline \multirow{2}{*}{$\begin{array}{l}\text { var } \\
2\end{array}$} & $\begin{array}{l}\text { Agricultural } \\
\text { sector }\end{array}$ & $\begin{array}{c}5 \\
(9.81) \\
\end{array}$ & $\begin{array}{c}2 \\
(3.92) \\
\end{array}$ & $\begin{array}{c}9 \\
(17.65) \\
\end{array}$ & $\begin{array}{c}6 \\
(11.76) \\
\end{array}$ & $\begin{array}{c}11 \\
(21.57) \\
\end{array}$ & $\begin{array}{c}10 \\
(19.61)\end{array}$ & $\begin{array}{c}8 \\
(15.69) \\
\end{array}$ \\
\hline & $\begin{array}{l}\text { Food produ- } \\
\text { ction sector }\end{array}$ & $\begin{array}{c}16 \\
(31.37) \\
\end{array}$ & $\begin{array}{c}5 \\
(9.81)\end{array}$ & $\begin{array}{c}3 \\
(5.88)\end{array}$ & $\begin{array}{c}11 \\
(21.57)\end{array}$ & $\begin{array}{c}9 \\
(17.65)\end{array}$ & $\begin{array}{c}7 \\
(13.73) \\
\end{array}$ & $\begin{array}{c}0 \\
(0)\end{array}$ \\
\hline var & Agricultural & 5 & 10 & 11 & 7 & 8 & 7 & 3 \\
\hline
\end{tabular}




\begin{tabular}{|c|c|c|c|c|c|c|c|c|}
\hline \multirow[t]{2}{*}{3} & sector & $(9.81)$ & (19.61) & (21.57) & $(13.73)$ & (15.69) & (13.73) & (5.88) \\
\hline & $\begin{array}{l}\text { Food produ- } \\
\text { ction sector }\end{array}$ & $\begin{array}{c}0 \\
(0)\end{array}$ & $\begin{array}{c}6 \\
(11.77)\end{array}$ & $\begin{array}{c}5 \\
(9.80)\end{array}$ & $\begin{array}{c}5 \\
(9.80)\end{array}$ & $\begin{array}{c}10 \\
(19.61)\end{array}$ & $\begin{array}{c}18 \\
(35.29)\end{array}$ & $\begin{array}{c}7 \\
(13.73)\end{array}$ \\
\hline \multirow{2}{*}{$\begin{array}{l}\text { var } \\
4\end{array}$} & $\begin{array}{l}\text { Agricultural } \\
\text { sector }\end{array}$ & $\begin{array}{c}7 \\
(13.73)\end{array}$ & $\begin{array}{c}6 \\
(11.76)\end{array}$ & $\begin{array}{c}9 \\
(17.65)\end{array}$ & $\begin{array}{c}10 \\
(19.61)\end{array}$ & $\begin{array}{c}8 \\
(15.69)\end{array}$ & $\begin{array}{c}7 \\
(13.73)\end{array}$ & $\begin{array}{c}4 \\
(7.84)\end{array}$ \\
\hline & $\begin{array}{l}\text { Food produ- } \\
\text { ction sector }\end{array}$ & $\begin{array}{c}1 \\
(1.96)\end{array}$ & $\begin{array}{c}7 \\
(13.73)\end{array}$ & $\begin{array}{c}10 \\
(19.61)\end{array}$ & $\begin{array}{c}8 \\
(15.69)\end{array}$ & $\begin{array}{c}11 \\
(21.57)\end{array}$ & $\begin{array}{c}11 \\
(21.57)\end{array}$ & $\begin{array}{c}3 \\
(5.88)\end{array}$ \\
\hline
\end{tabular}

Legend 1:1 - strongly disagree, 2 - disagree, 3 - slightly disagree, 4 - neither agree nor disagree, 5 - to some extent agree, 6 - agree, 7 - totally agree

Source: Own research

Table 4. Frequency response to the above-mentioned questions (by marked variables) of respondents from agricultural sector and the sector of food production

\begin{tabular}{|c|c|c|c|c|c|c|c|c|}
\hline \multicolumn{2}{|c|}{$\begin{array}{l}\text { Offered responses } \\
\text { Frequency N } \\
(\text { Percent \%) }\end{array}$} & $\begin{array}{c}1 \\
\mathrm{~N} \\
(\%)\end{array}$ & $\begin{array}{c}2 \\
\mathrm{~N} \\
(\%)\end{array}$ & $\begin{array}{c}3 \\
\mathrm{~N} \\
(\%)\end{array}$ & $\begin{array}{c}4 \\
\mathrm{~N} \\
(\%)\end{array}$ & $\begin{array}{c}5 \\
\mathrm{~N} \\
(\%)\end{array}$ & $\begin{array}{c}6 \\
\mathrm{~N} \\
(\%)\end{array}$ & $\begin{array}{c}7 \\
\mathrm{~N} \\
(\%) \\
\end{array}$ \\
\hline \multirow[b]{2}{*}{$\operatorname{var} 5$} & Agricultural sector & $\begin{array}{c}6 \\
(11.76) \\
\end{array}$ & $\begin{array}{c}7 \\
(13.73) \\
\end{array}$ & $\begin{array}{c}9 \\
(17.65) \\
\end{array}$ & $\begin{array}{c}9 \\
(17.65) \\
\end{array}$ & $\begin{array}{c}13 \\
(25.49) \\
\end{array}$ & $\begin{array}{c}5 \\
(9.80) \\
\end{array}$ & $\begin{array}{c}2 \\
(3.92) \\
\end{array}$ \\
\hline & Food produ-ction sector & $\begin{array}{c}1 \\
(1.96)\end{array}$ & $\begin{array}{c}4 \\
(7.84)\end{array}$ & $\begin{array}{c}4 \\
(7.84)\end{array}$ & $\begin{array}{c}9 \\
(17.65)\end{array}$ & $\begin{array}{c}15 \\
(29.41) \\
\end{array}$ & $\begin{array}{c}9 \\
(17.65) \\
\end{array}$ & $\begin{array}{c}9 \\
(17.65) \\
\end{array}$ \\
\hline \multirow{2}{*}{$\operatorname{var} 6$} & Agricultural sector & $\begin{array}{c}8 \\
(15.69)\end{array}$ & $\begin{array}{c}6 \\
(11.76)\end{array}$ & $\begin{array}{c}9 \\
(17.65)\end{array}$ & $\begin{array}{c}7 \\
(13.73)\end{array}$ & $\begin{array}{c}9 \\
(17.65)\end{array}$ & $\begin{array}{c}11 \\
(21.57)\end{array}$ & $\begin{array}{c}1 \\
(1,96)\end{array}$ \\
\hline & Food produ-ction sector & $\begin{array}{c}1 \\
(1.96)\end{array}$ & $\begin{array}{c}4 \\
(7.84)\end{array}$ & $\begin{array}{c}10 \\
(19.61)\end{array}$ & $\begin{array}{c}15 \\
(29.41)\end{array}$ & $\begin{array}{c}9 \\
(17.65)\end{array}$ & $\begin{array}{c}9 \\
(17.65)\end{array}$ & $\begin{array}{c}3 \\
(5.88)\end{array}$ \\
\hline
\end{tabular}

Legend 2:1 - never, 2 - rarely, 3 - from time to time, 4 - sometimes, 5 - often, 6 - usually, 7 - always Source: Own research

Industry is turning to other priorities that include innovation and development. Although the agriculture in Serbia went through similar processes, some of the problems remained present, such as unfavorable agrarian structure, unresolved property relations, the lack of organization of agricultural producers and lack of competitiveness. The Strategy for Agriculture and Rural Development of the Republic of Serbia for the period 2014-2024 (2014) aims to define the directions of future development based on the sustainable management of natural resources, if you look at the results obtained during the research of agricultural and food sectors, we can conclude that the food sector $(31.38 \%)$ tend to be more open to innovation in relation to agricultural one $(23.86 \%)$. The reasons for this may lie in the traditionally more conservative nature of the participants in agriculture compared to those in the industry, but also somewhat different processes that occurred in these two sectors during the process of transition to a market economy. Some of the key processes in the past in the food industry in Serbia were related to ownership transformation of enterprises, restructuring, taking into account the technological excess, assistance programs, return to profitability and this period is about to end.

Now the food increasing production, competitiveness and accelerated development and introduction of agrarian policy instruments that allow dynamic restructuring of the agricultural sector.

Seen by elements from both major dimensions of access to open innovation, technology exploitation and exploration technology, the food sector has an advantage in terms of venturing, employee involvement, outsourcing R \& D \& external networking, customer involvement and external participation. However, in terms of willingness to sell intellectual property to other organizations the agricultural sector shows a lot higher score. In accordance with this result, companies in the food industry are still averse to sell the intellectual property rights that present one source of their competitive advantage to other organizations.

This study has several limitations. The research of proclivity for open innovation has been carried out on a sample of companies in the agricultural and food sectors in Serbia. The research sample of companies from several countries could be compared in order to determine 
the differences in organizational and environmental settings of different countries. Furthermore, this study did not take into account the differences between enterprises in terms of size, year of establishment, realized profits and other parameters. Future studies could determine whether there are differences in the proclivity for open innovation between different groups of companies. Sure, the very construct and measures of the proclivity for open innovation may be a subject of change.

\section{Conclusion}

Proclivity for open innovation in the agro-food sector in the researched sample of companies in the agro-food sector in Serbia is $27.62 \%$. This result supports the attitude in literature that a preference for open innovation is also shown in companies that are not in high tech industries, and also in small and medium-sized enterprises.

A greater preference for open innovation in the researched sample was shown by companies in the food sector compared to companies in agriculture. We believe that the problem here is less in connection with the general food industry being more prone to innovation than agriculture. A part of the reasons is of local nature due to slower restructuring of agricultural sector in Serbia in the period of transition compared to the food sector.

Food industry in Serbia on the researched sample of enterprises has an advantage in five elements of the proclivity for open innovation in comparison with agriculture. However, the difference was significantly decreased by the question of willingness to sell intellectual property which indicates that the concept of open innovation presents a challenge for managers and that the traditional paradigm of innovation as a closed firm-level activity is still strong especially when it comes to intellectual property.

It is recommended to research the proclivity for open innovation in the agro-food sector in different countries with a uniform research instrument.

\section{REFERENCES}

1. Acosta, M., Coronado, D., Toribio, M.R. (2011). The use of scientific knowledge by Spanish agrifood firms. Food Policy, 36,4, 507-516.

2. Chesbrough, H.W. (2003). Open innovation: the new imperative for creating and profiting from technology. Boston, US, Harvard Business School Press.

3. Chesbrough, H.W., Crowther, A.K. (2006). Beyond high tech: early adopters of open innovation in other industries. R \& D Management, 36,3, 229-236.

4. Chesbrough, H.W, Vanhaverbeke, W., West, J. (2006). Open innovation: researching a new paradigm. London, UK, Oxford University Press.

5. Dahlander, L., Gann, D.M. (2010): How open is innovation? Research Policy, 39,6, 699-709.

6. Government of the Republic of Serbia (2011). Strategy and policy development of the industry of the Republic of Serbia 2011-2020. Official Gazette of the Republic of Serbia, 55/2011. Belgrade.

7. Government of the Republic of Serbia, (2014). Strategy for agriculture and rural development of the Republic of Serbia for the period 2014-2024. Official Gazette of the Republic of Serbia, 85/2014. Belgrade.

8. Hossain, M. (2015). A review of literature on open innovation in small and medium-sized enterprises. Journal of Global Entrepreneurship Research, 5,6, 2-12.

9. Huizingh, E.K.R.E. (2011). Open innovation: state of the art and future perspectives. Technovation, 31,1, 2-9.

10. Hung, K.P., Chiang, Y.H. (2010). Open innovation proclivity, entrepreneurial orientation, and perceived firm performance. International Journal of Technology Management, 52,3/4, 257-274.

11. Matras-Bolibok, A., Kis, K. (2014). European innovation partnership as a framework for open innovation in agriculture. Annals of The Polish Association of Agribusiness Economists, 16,6, 339-344. 
12. Pishbin, S.A.R., Alambeigi, A., Iravani. H. (2015). Investigation of the role of structural, leadership, and strategy factors in cooperatives entrepreneurship. Journal of Agricultural Science and Technology, 17, 1115-1125.

13. Rangus, K. (2014). Proclivity for open innovation: construct development, determinants and outcomes. Doctoral thesis. Ljubljana, Slovenia: University of Ljubljana.

14. Sarkar, S., Costa, A.I.A. (2008). Dynamic of open innovation in the food industry. Trends in Food, Science and Technology, 19,11, 574-580.

15. Schueffel, P. (2014). The effects of entrepreneurial orientation on innovation performance, open innovation proclivity and openness. 2014 Annual Meeting of the Academy of Management, 1-5 August 2014, Philadelphia, US.

16. Van de Vrande, V., de Jongb, J.P.J., Vanhaverbeke, W., de Rochemont M. (2009). Open innovation in SMEs: trends, motives and management challenges. Technovation, 29,6-7, 423437.

17. Venturiny, K., Verbano, C., Bron, A. (2013). Openness and innovation: an empirical analysis in firms located in Republic of San Marino. International Journal of Engineering, Science and Technology, 5,4, 60-70.

18. Vukovic, D., Markovic, D., Hanic, A. (2016). Snowflake model of regional competitiveness evidence from Serbia. International Review, 1-2, 59-73.

\section{Article history:}

- $\quad$ Received 17 May 2017

- $\quad$ Accepted 10 October 2017 